\title{
"Bright tongue sign" in ALS
}

Figure Brain MRI

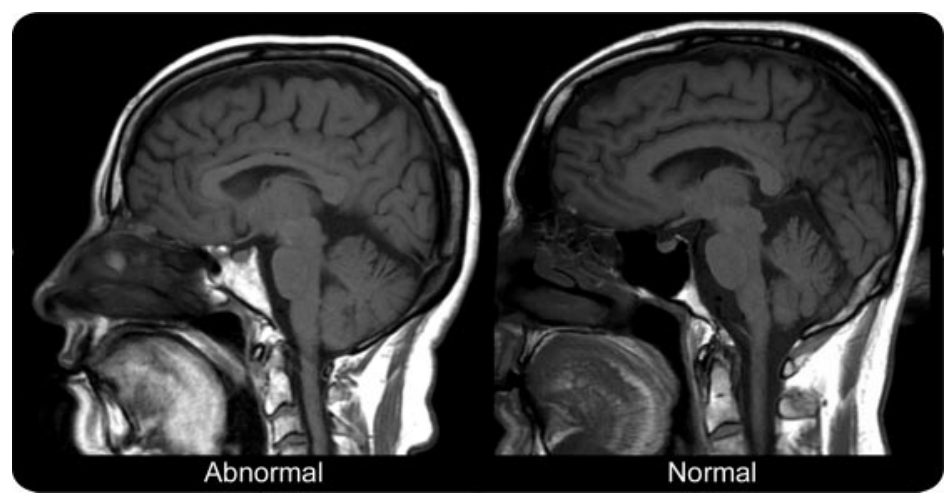

Sagittal T1 MRI of the brain shows abnormal diffuse T1 hyperintensity of the tongue musculature (left). A normal tongue is shown on the right.

A 62-year-old woman presented with 1 year of slowly progressive dysarthria, difficulty chewing food, sialorrhea, dysphagia, and unintentional 20-pound weight loss. Neurologic examination demonstrated moderate dysarthria, marked tongue weakness with atrophy and fasciculations, multifocal muscular atrophy, and diffuse hyperreflexia, including a jaw jerk. EMG showed diffuse fibrillation potentials and positive sharp waves. The history, examination, and EMG results fulfilled diagnostic criteria for amyotrophic lateral sclerosis. Brain MRI showed pronounced T1 hyperintensity of the tongue, consistent with chronic denervation of the tongue musculature with fatty replacement (figure). ${ }^{1,2}$

Michael D. Fox, MD, PhD, Adam B. Cohen, MD, Boston, MA

The authors report no disclosures relevant to the manuscript. Go to Neurology.org for full disclosures.

Correspondence \& reprint requests to Dr. Fox: foxmdphd@gmail.com

1. Konagaya M, Konagaya Y, Konishi T, Mano Y. [MRI findings of the tongue in neurodegenerative diseases with bulbar sign.] Rinsho Shinkeigaku 1990;30:665-667.

2. Cha CH, Patten BM. Amyotrophic lateral sclerosis: abnormalities of the tongue on magnetic resonance imaging. Ann Neurol $1989 ; 25: 468-472$. 


\title{
Neurology
}

\author{
"Bright tongue sign" in ALS \\ Michael D. Fox and Adam B. Cohen \\ Neurology 2012;79;1520 \\ DOI 10.1212/WNL.0b013e31826d5ffc
}

\section{This information is current as of October 1, 2012}

\section{Updated Information \& Services}

\section{References}

Subspecialty Collections

Permissions \& Licensing

\section{Reprints}

including high resolution figures, can be found at: http://n.neurology.org/content/79/14/1520.full

This article cites 2 articles, 0 of which you can access for free at: http://n.neurology.org/content/79/14/1520.full\#ref-list-1

This article, along with others on similar topics, appears in the following collection(s):

Amyotrophic lateral sclerosis

http://n.neurology.org/cgi/collection/amyotrophic_lateral_sclerosis_ EMG

http://n.neurology.org/cgi/collection/emg

MRI

http://n.neurology.org/cgi/collection/mri

Information about reproducing this article in parts (figures,tables) or in its entirety can be found online at:

http://www.neurology.org/about/about_the_journal\#permissions

Information about ordering reprints can be found online:

http://n.neurology.org/subscribers/advertise

Neurology ${ }^{\circledR}$ is the official journal of the American Academy of Neurology. Published continuously since 1951, it is now a weekly with 48 issues per year. Copyright Copyright (? 2012 by AAN Enterprises, Inc.. All rights reserved. Print ISSN: 0028-3878. Online ISSN: 1526-632X.

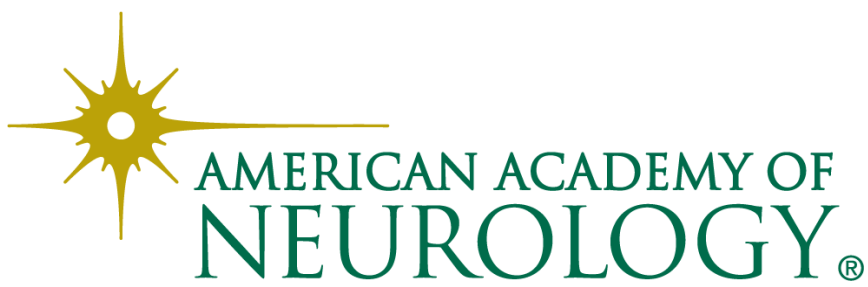

